\title{
Alterations of fatty acid $\beta$-oxidation capability in the liver of ketotic cows
}

\author{
P. Li,${ }^{*}{ }^{1}$ X. B. Li ${ }^{\star 1}{ }^{1}$ S. X. Fu, ${ }^{*}$ C. C. Wu, ${ }^{*}$ X. X. Wang, ${ }^{*}$ G. J. Yu, ${ }^{*}$ M. Long, $†$ Z. Wang, ${ }^{*}$ and G. W. Liu ${ }^{\star 2}$ \\ ${ }^{*}$ Department of Clinical Veterinary Medicine, College of Animal Science and Veterinary Medicine, Jilin University, Changchun 130062, Jilin, China \\ †College of Animal Science and Veterinary Medicine, Shenyang Agricultural University, Shenyang 110161, Liaoning, China
}

\begin{abstract}
Dairy cows are highly susceptible to ketosis after parturition. In the present study, we evaluated the expression of fatty acid $\beta$-oxidation-related enzymes in the liver of ketotic $(\mathrm{n}=6)$ and nonketotic $(\mathrm{n}=6)$ cows. Serum levels of nonesterified fatty acids (NEFA), $\beta$-hydroxybutyrate (BHBA), and glucose were determined by using standard biochemical techniques. The mRNA abundance and protein content of acyl-CoA synthetase long-chain (ACSL), carnitine palmitoyltransferase I (CPT I), carnitine palmitoyltransferase II (CPT II), acyl-CoA dehydrogenase long chain (ACADL), 3-hydroxy-3-methylglutaryl-CoA synthase (HMGCS), and acetyl-CoA carboxylase (ACC) were evaluated by real-time PCR and ELISA. We found that serum glucose levels were lower in ketotic cows than in nonketotic cows, but serum BHBA and NEFA concentrations were higher. Messenger RNA and protein levels of ACSL were significantly higher in livers of ketotic cows than those in nonketotic cows. In contrast, mRNA levels of CPT I and mRNA and protein levels of CPT II, ACADL, HMGCS, and ACC were decreased in the liver of ketotic cows. Serum NEFA concentration positively correlated with ACSL protein levels and negatively correlated with protein levels of $\mathrm{CPT}$ II, HMGCS, ACADL, and ACC. In addition, serum BHBA concentration negatively correlated with protein levels of CPT II, HMGCS, and ACADL. Overall, fatty acid $\beta$-oxidation capability was altered in the liver of ketotic compared with nonketotic cows. Furthermore, high serum NEFA and BHBA concentrations play key roles in affecting pathways of fatty acid metabolism in the liver.
\end{abstract}

Key words: ketosis, liver, fatty acid, $\beta$-oxidation

\section{INTRODUCTION}

Metabolic disorders and infectious diseases such as ketosis are common in dairy cows during the peripar-

Received May 27, 2011.

Accepted December 14, 2011.

${ }^{1} \mathrm{P}$. Li and X. B. Li contributed equally to this study.

${ }^{2}$ Corresponding author: liuguowen2008@163.com turient period (Goff and Horst, 1997). High concentrations of NEFA and ketone bodies (acetoacetate, BHBA, acetone) and concurrent low blood glucose levels in early lactating dairy cows are indicative of a negative energy balance (Grummer, 1995; Melendez et al., 2006). Subclinical ketosis is generally diagnosed when plasma BHBA concentration exceeds $1.2 \mathrm{mmol} / \mathrm{L}$ (Duffield, 2000; Geishauser et al., 2000).

As a metabolic disease, ketosis is closely associated with liver lipidosis. Although progress has been made in understanding the pathology and etiology of liver lipidosis and ketosis in dairy cattle, the underlying mechanisms remain unclear. Liver lipidosis develop when the hepatic uptake of NEFA exceeds their oxidation and secretion as triacylglycerol in very low density lipoproteins (Drackley et al., 2001). This disorder affects the health, well-being, productivity, and reproductive performance of cows (Bobe et al., 2004).

Hepatic oxidation of long-chain FA occurs in mitochondria and peroxisomes (Drackley et al., 2001). The 4 steps of mitochondrial FA oxidation are (1) uptake and activation of fatty acids to fatty acyl-CoA; (2) translocation of fatty acyl-CoA into the mitochondria; (3) $\beta$-oxidation of fatty acyl-CoA; and (4) ketogenesis (Louet et al., 2001). Vernon et al. (2003) demonstrated that postpartum ketosis in cows is not due to significant changes in the activity of liver enzymes involved in fatty acid metabolism. Carnitine palmitoyltransferase I (CPT I) activity is positively correlated with liver total lipid, liver triglyceride, liver triglyceride to glycogen ratio, and serum NEFA (Dann and Drackley, 2005). Carnitine palmitoyltransferase I does not appear to be involved in the etiology of primary ketosis, because CPT I activity or sensitivity is not altered in primary ketosis or other periparturient disorders. Instead, postpartum ketosis may result from lower FA oxidation following parturition, the reduced activity of acetylCoA carboxylase, fatty acid synthase, and 3-hydroxyacyl-CoA dehydrogenase (Murondoti et al., 2004). Our laboratory previously reported that the expression of acetyl-CoA acetyltransferase 2 and 3-hydroxyacyl-CoA dehydrogenase type-2, enzymes involved in FA oxidation metabolism, were lowered in the liver of ketotic cows, which indicate that FA oxidation might be de- 
Table 1. Parity, BW, and milk production of ketotic and nonketotic cows (means $\pm \mathrm{SE}$ )

\begin{tabular}{lcc}
\hline Item & $\begin{array}{c}\text { Ketotic cows } \\
(\mathrm{n}=6)\end{array}$ & $\begin{array}{c}\text { Nonketotic cows } \\
(\mathrm{n}=6)\end{array}$ \\
\hline Parity & $3.8 \pm 0.9$ & $3.5 \pm 1.1$ \\
BW $(\mathrm{kg})$ & $605.33 \pm 62.15^{*}$ & $653.64 \pm 54.36$ \\
Milk production $(\mathrm{kg} / \mathrm{d})$ & $26.23 \pm 4.35^{*}$ & $30.38 \pm 3.73$ \\
\hline$P<0.05$. & &
\end{tabular}

creased (Xu and Wang, 2008; Xu et al., 2010), but the results are limited.

A better understanding of lipid metabolism, especially in FA activation, translocation, $\beta$-oxidation, and ketogenesis in mitochondria, may facilitate the development of nutritional and management approaches to prevent metabolic disorders such as ketosis in dairy cows. In this study, we investigated FA metabolism in ketotic cows and nonketotic cows by evaluating the expression of FA oxidation-related enzymes in liver tissue specimens.

\section{MATERIALS AND METHODS}

\section{Animals and Specimen Collection}

All animals used in this study were treated according to International Guiding Principles for Biomedical Research Involving Animals (Xu and Wang, 2008). All the lactating Holstein multiparous cows were selected from a commercial dairy farm (Qingxin) located in Heilongjiang Province, China. Three hundred twenty-seven cows in postpartum wk 4 were screened to identify ketotic cows. According to blood parameters and clinical signs, 26 cows with high BHBA levels were obtained and, of these, 15 cows showed obvious signs of ketosis. Finally, in consideration of parity, BW, and milk production, 6 cows were selected as ketotic cows, having high BHBA levels (BHBA $>1.2 \mathrm{mmol} / \mathrm{L}$, glucose $<2.5$ $\mathrm{mmol} / \mathrm{L}$, and NEFA $>500 \mu \mathrm{mol} / \mathrm{L}$ ) and obvious signs of ketosis. In addition, 6 cows with low BHBA levels (BHBA $<0.60 \mathrm{mmol} / \mathrm{L}$, glucose $>3.75 \mathrm{mmol} / \mathrm{L}$, and NEFA $<400 \mu \mathrm{mol} / \mathrm{L}$ ) and no obvious signs of ketosis were selected as nonketotic cows. The criterion for subclinical ketosis in the cow is plasma BHBA $>1.2$ mmol/L (Ingvartsen, 2006; Melendez et al., 2006; Xu et al., 2010), whereas plasma glucose and NEFA are the reference factors. All 6 ketotic cows had symptoms of rapid deterioration of body condition, loss of appetite, decreased milk production, hypoglycemia, and hyperketonemia. All nonketotic cows had normal appetite, body temperature, pulse rate, and breathing. Parity, $\mathrm{BW}$, and milk production of the experimental cows are shown in Table 1.
All cows were fed the same diet during the dry period and early lactation. A blood sample was taken from the jugular vein just before the liver biopsies were obtained. Jugular vein blood was centrifuged immediately after collection at $4,000 \times g$ for $10 \mathrm{~min}$; the plasma was collected and frozen at $-20^{\circ} \mathrm{C}$. All blood specimens were handled similarly and anticoagulant was not used. Liver tissue samples were taken from the 11th or 12th right intercostal space by liver transfixion pin (Shanghai Surgical Equipment Factory, Shanghai, China) after blood collection. The liver tissue biopsies were quickly washed in cold buffer containing $0.2 \mathrm{mM}$ protease inhibitor cocktail (Roche, Mannheim, Germany), oxacillin (Sigma-Aldrich Co., St. Louis, MO), gentamycin (Sigma-Aldrich Co.), penicillin (Sigma-Aldrich Co.), streptomycin (Sigma-Aldrich Co.), amphotericin B (Sigma-Aldrich Co.), and nystatin (Sigma-Aldrich Co.) to remove cell debris and blood, and were then frozen in liquid nitrogen.

\section{Analysis of Plasma Metabolites}

Concentrations of plasma glucose (glucose oxidase method, Yulan Biotechnology Research Institute, Shanghai, China), BHBA (enzymatic method, Randox Laboratories Ltd., Ibach, Switzerland), and NEFA (enzymatic method, Yulan Biotechnology Research Institute) were analyzed according to the manufacturer's directions.

\section{RNA Extraction and Real-Time Reverse Transcription-PCR}

Total RNA was isolated from liver specimens using RNAiso Plus [TaKaRa Biotechnology (Dalian) Co., Ltd., Dalian, China] according to the manufacturer's instructions and quantified by spectrophotometry with a BioPhotometer (Vaudaux-Eppendorf, Basel, Switzerland). Then, $1 \mu \mathrm{g}$ of total RNA was reverse transcribed with $200 \mathrm{U}$ of Moloney Murine Leukemia Virus Reverse Transcriptase RNase H Minus, Point Mutant (Promega, Madison, WI) using $100 \mathrm{pmol}$ of random hexamer primers (Invitrogen, Leek, the Netherlands). The cDNA $(25 \mathrm{ng} / \mu \mathrm{L})$ was amplified by real-time PCR 
using SYBR Premix Ex Taq II [TaKaRa Biotechnology (Dalian) Co., Ltd.] according to the manufacturer's instructions. A master mix of the following reaction components was prepared: $6 \mu \mathrm{L}$ of water, $0.8 \mu \mathrm{L}$ of forward primer $(10 \mu \mathrm{mol} / \mathrm{L}), 0.8 \mu \mathrm{L}$ of reverse primer $(10 \mu \mathrm{mol} / \mathrm{L}), 10 \mu \mathrm{L}$ of SYBR Premix Ex Taq II $(2 \times)$, and $0.4 \mu \mathrm{L}$ of ROX reference dye $(50 \times)$. Eighteen microliters of master mix and $2 \mu \mathrm{L}$ of sample volume, containing $50 \mathrm{ng}$ of cDNA, were used. Then, the following 2-step PCR program was used: denaturation for 30 $\mathrm{s}$ at $95^{\circ} \mathrm{C}, 40$ cycles of amplification (each consisting of $5 \mathrm{~s}$ at $95^{\circ} \mathrm{C}, 60^{\circ} \mathrm{C}$ for $30 \mathrm{~s}$ ), and finally a melting curve program $\left(60-95^{\circ} \mathrm{C}\right)$. Expression of acyl-CoA synthetase long-chain (ACSL), CPT I, carnitine palmitoyltransferase II (CPT II), acyl-CoA dehydrogenase long chain (ACADL), 3-hydroxy-3-methylglutaryl-CoA synthase (HMGCS), acetyl-CoA carboxylase (ACC), and $\beta$-actin genes was evaluated on the basis of mRNA copy number per microgram of total RNA. The $\beta$-actin gene was also analyzed to monitor real-time PCR efficiencies and to provide an internal reference. Target gene mRNA abundance was displayed as the target gene mRNA copy number per microgram of total RNA/ $\beta$ actin mRNA copy number (Xu et al., 2011). Primers for CPT I were identical to those used in van Dorland et al. (2009), and primers for ACSL, CPT II, ACADL, HMGCS, ACC and $\beta$-actin were designed with Primer Express Version 2.0 software (PE Applied Biosystems, Foster, CA; Table 2).

\section{Liver Protein Concentrations of ACSL, CPT I, CPT II, ACADL, HMGCS, and ACC}

Each liver specimen (approximately $20 \mathrm{mg}$ ) was crushed in a mortar containing liquid nitrogen and was mixed with $400 \mu \mathrm{L}$ of Tris-HCl $(50 \mathrm{mM})$. The liver tissue was centrifuged for $10 \mathrm{~min}$ at $2,500 \times \mathrm{g}$. The su- pernatant $(10 \mu \mathrm{L})$ was diluted 100 times, and the total protein concentration was determined with the Bradford method (Bradford, 1976) using BSA as a standard.

All of the following kits were obtained from Cusabio Biotech Co. Ltd. (Wuhan, China) and were used according to the manufacturer's instructions. Acyl-CoA synthetase long-chain protein was measured by using the bovine acyl-CoA synthase ELISA kit (cat. no. CSBE12165B), with a minimum detectable concentration of $0.39 \mathrm{ng} / \mathrm{mL}$. Carnitine palmitoyltransferase I protein was measured by using the bovine carnitine palmitoyltransferase I ELISA kit (cat. no. CSB-E12136B) with a minimum detectable concentration of $0.31 \mathrm{ng} / \mathrm{mL}$, and CPT II protein was measured by using the bovine carnitine palmitoyltransferase II ELISA kit (cat. no. CSB-E12137B), with a minimum detectable concentration of $1.95 \mathrm{ng} / \mathrm{mL}$. Acyl-CoA dehydrogenase long chain protein was measured by using the bovine acylCoA dehydrogenase, long-chain ELISA kit (cat. no. CSB-E12138B), with a minimum detectable concentration of $3.12 \mathrm{ng} / \mathrm{mL}$. 3-Hydroxy-3-methylglutaryl-CoA synthase protein was measured by using the bovine 3-hydroxy-3-methylglutaryl-CoA synthase ELISA kit (cat. no. CSB-E12140B), with a minimum detectable concentration of $0.78 \mathrm{ng} / \mathrm{mL}$. Acetyl-CoA carboxylase protein was measured by using the bovine acyl-CoA carboxylase ELISA kit (cat. no. CSB-E12139B), with a minimum detectable concentration of $0.78 \mathrm{ng} / \mathrm{mL}$. Each factor for one specimen was measured in triplicate. Protein levels of ACSL, CPT I, CPT II, ACADL, HMGCS, and ACC were calculated in relation to total liver protein.

\section{Statistical Analysis}

Statistical analysis of the data was carried out by using SPSS 13.0 software (SPSS Inc., Chicago, IL) with

Table 2. Primers used in PCR to analyze FA metabolism-related genes

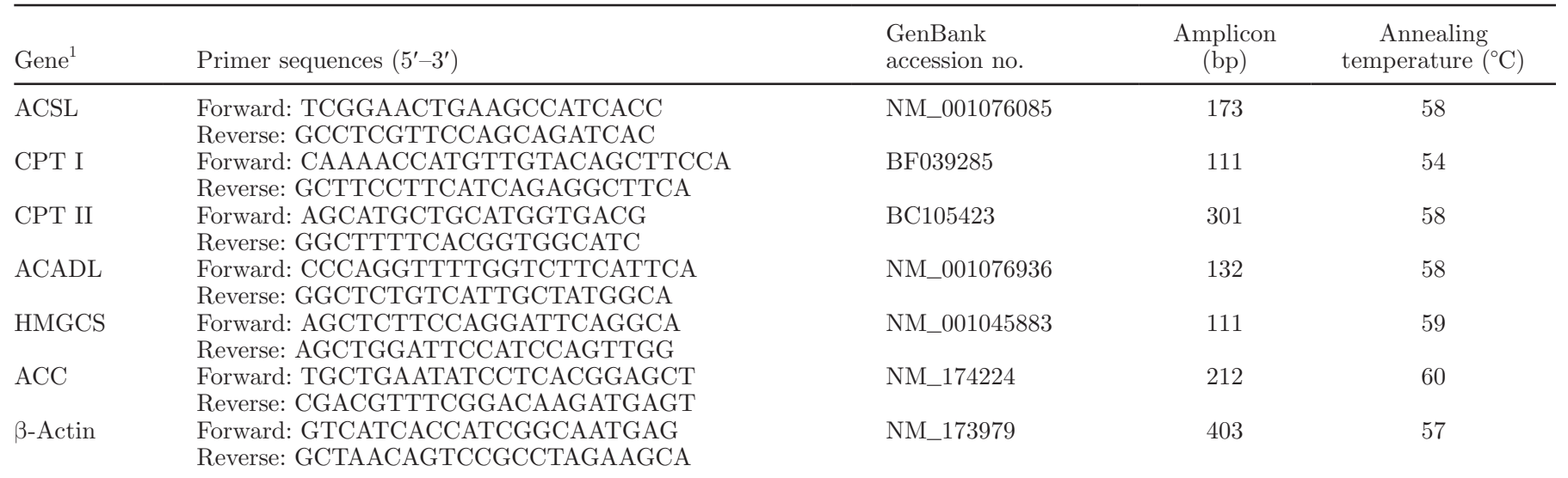

${ }^{1} \mathrm{ACSL}=$ acyl-CoA synthetase long-chain; ACADL $=$ acyl-CoA dehydrogenase long chain; CPT I = carnitine palmitoyltransferase I; CPT II $=$ carnitine palmitoyltransferase II; HMGCS = 3-hydroxy-3-methylglutaryl CoA synthase; ACC = acyl-CoA carboxylase. 
a significance level set at $P<0.05$. Serum and liver parameters of ketotic and nonketotic cows were compared by one-way ANOVA with the use of Duncan's test. Results were expressed as mean \pm standard error (SE). The bivariate correlations procedure of SPSS with the Pearson option (2-tailed) was used to determine correlations between serum NEFA, BHBA, glucose concentrations and ACSL, CPT I, CPT II, ACADL, HMGCS, and ACC protein content in the liver of the experimental cows.

\section{RESULTS}

\section{BHBA, NEFA, and Glucose Concentrations in Ketotic and Nonketotic Cows}

Compared with nonketotic cows, ketotic cows exhibited higher serum BHBA levels, lower serum glucose levels, and higher serum NEFA levels (Table 3 ). These differences were significant $(P<0.05)$.

\section{Relative mRNA and Protein Levels of FA Metabolism-Related Enzymes in the Liver}

Real-time PCR analysis was carried out to evaluate the expression of FA metabolism-related genes in the liver. Expression of the ACSL gene was increased 5.7fold in ketotic cows compared with nonketotic cows $(P$ $<0.01$; Figure 1). However, mRNA abundance of CPT I, CPT II, ACADL, HMGCS, and ACC were decreased by $18,70,44,52$, and $64 \%$, respectively, in ketotic cows compared with nonketotic cows $(P<0.05$; Figure 1$)$.
Compared with nonketotic cows, ACSL protein levels in the liver of ketotic cows were significantly higher, whereas levels of CPT II, ACADL, HMGCS, and ACC were significantly lower (Table 4). In addition, CPT I levels were lower in ketotic cows but similar to those in nonketotic cows.

\section{Relationship Between Serum Levels of BHBA, NEFA, and Glucose and Protein Levels of ACSL, CPTI, CPTII, ACADL, HMGCS, and ACC in the Liver}

Serum glucose concentration did not appear to be associated with protein levels of ACSL, CPT I, CPT II, ACADL, HMGCS, or ACC in the liver of experimental cows (6 ketotic cows and 6 nonketotic cows). However, serum NEFA concentration was negatively correlated with protein levels of CPT II $(\mathrm{r}=-0.814, P=0.001)$, HMGCS $(\mathrm{r}=-0.632, P=0.027)$, ACADL $(\mathrm{r}=$ $-0.751, P=0.005)$, and ACC $(\mathrm{r}=-0.667, P=0.018)$ and positively correlated with ACSL $(\mathrm{r}=0.688, P=$ 0.013) in experimental cows (Figure 2). Serum BHBA concentration was negatively correlated with protein levels of CPT II ( $\mathrm{r}=-0.654, P=0.021)$, HMGCS (r $=-0.611, P=0.035)$, and ACADL $(\mathrm{r}=-0.658, P=$ 0.020 ) in experimental cows (Figure 3 ).

\section{DISCUSSION}

Ketosis is an important disease connected with negative energy balance. Cows in early lactation mainly use glucose for milk production and DMI is depressed. As a result, lipolysis occurs to provide precursors to

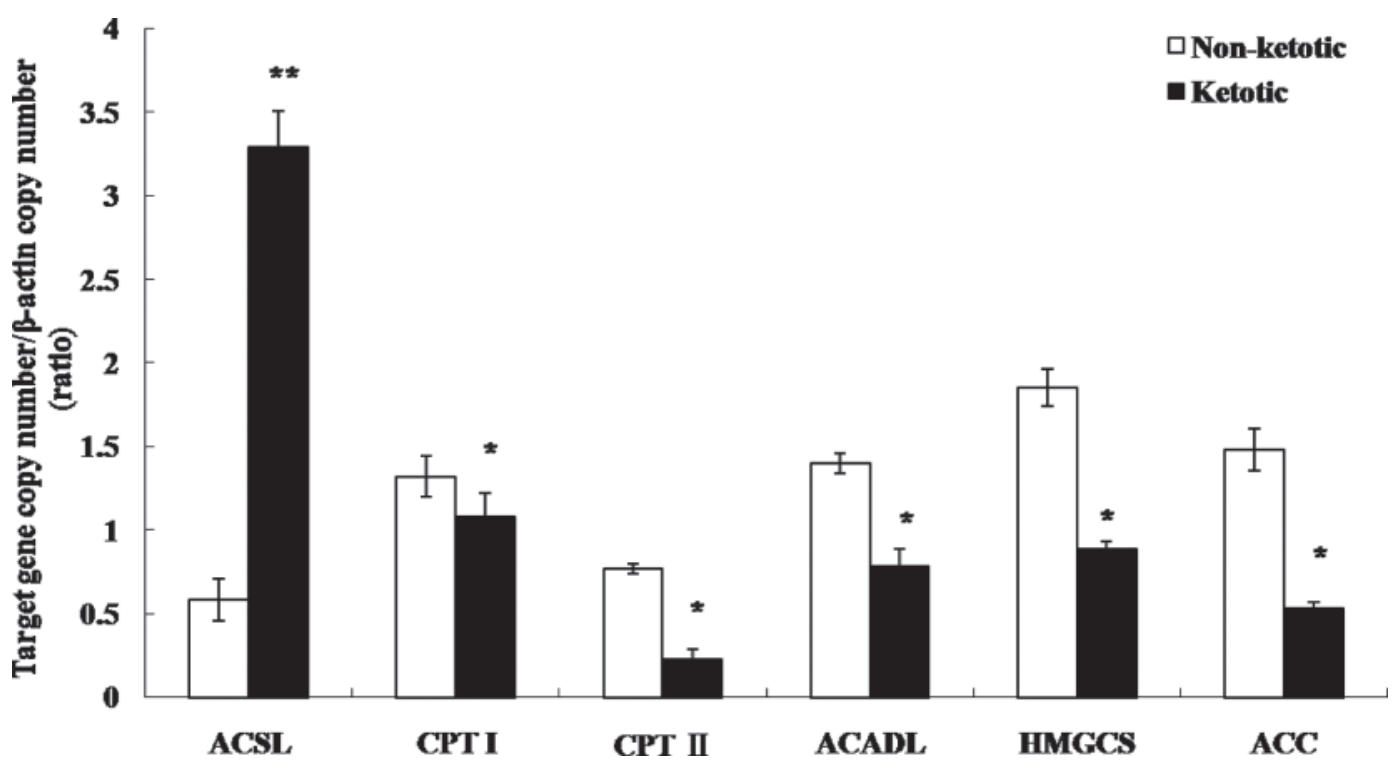

Figure 1. Real-time reverse transcription-PCR analysis of fatty acid metabolism-related enzymes in the liver. Values are reported as target gene mRNA copy number of $1 \mu \mathrm{g}$ of total RNA/ $\beta$-actin mRNA copy number. ${ }^{*} P<0.05 ; * * P<0.01$. Error bars indicate standard errors. 
Table 3. Serum BHBA, NEFA, and glucose concentrations of ketotic and nonketotic cows (means $\pm \mathrm{SE}$ )

\begin{tabular}{lcc}
\hline Item & $\begin{array}{c}\text { Ketotic cows } \\
(\mathrm{n}=6)\end{array}$ & $\begin{array}{c}\text { Nonketotic cows } \\
(\mathrm{n}=6)\end{array}$ \\
\hline BHBA $(\mathrm{mmol} / \mathrm{L})$ & $1.98 \pm 0.90^{*}$ & $0.48 \pm 0.22$ \\
NEFA $(\mu \mathrm{mol} / \mathrm{L})$ & $762.60 \pm 152.10^{*}$ & $272.70 \pm 62.30$ \\
Glucose $(\mathrm{mmol} / \mathrm{L})$ & $2.05 \pm 0.29^{*}$ & $4.36 \pm 0.85$ \\
\hline$P<0.05$. & &
\end{tabular}

yield energy in the form of ATP, which causes increases in serum NEFA concentration. The liver is the most active metabolic organ for cows to metabolize NEFA (Melendez et al., 2006), and NEFA in the liver are mainly metabolized via 3 pathways: (1) complete oxidation, producing $\mathrm{H}_{2} \mathrm{O}, \mathrm{CO}_{2}$, and ATP; (2) incomplete oxidation, producing ketones; and (3) esterification to triacylglyceride. Therefore, large amounts of NEFA will be incompletely oxidized to ketones or esterified to triacylglyceride when the uptake of NEFA exceeds the oxidation ability in the liver, thereby potentially leading to ketosis or liver lipidosis. However, details of the FA oxidation pathway in ketotic cows are not well characterized, especially in the activation, translocation, $\beta$-oxidation, and ketogenesis of FA.

In the present study, the serum glucose concentration of ketotic cows was lower than that of nonketotic cows $(P<0.05)$, but serum NEFA and BHBA concentrations were higher $(P<0.05)$. This result is consistent with previous findings (Xu and Wang, 2008). High NEFA concentrations suggest negative energy balance and enhanced lipolysis of adipose tissue after parturition. Similarly, the serum BHBA concentration of ketotic cows was higher than that of nonketotic cows, as has been reported previously (Busato et al., 2002; Hachenberg et al., 2007). Busato et al. (2002) observed peak NEFA concentration 1 wk before the peak BHBA concentration was detected in dairy cows. Thus, increased serum BHBA concentrations due to enhanced ketogenesis appear to occur after enhanced lipolysis, as indicated by elevated plasma NEFA levels. This increase in serum BHBA concentration in ketotic cows coincided with a lower concentration of glucose, suggesting a larger energy deficit in ketotic cows than that in nonketotic cows.

Acyl-CoA synthetase long-chain activates FA to fatty acyl-CoA either for FA oxidation or for triacylglyceride synthesis in the liver. van Dorland et al. (2009) reported that the mRNA expression of ACSL did not increase in high-BHBA cows (BHBA $>0.75 \mathrm{mmol} / \mathrm{L}$ ) compared with low-BHBA cows (BHBA $<0.75 \mathrm{mmol} / \mathrm{L}$ ) postpartum, which suggests that the high-BHBA cows were in a metabolic state in which it is not necessary to cover energy requirements by enhanced oxidation of longchain FA. However, in the present study, the expression and protein level of ACSL were higher in the liver of ketotic compared with nonketotic cows. The significant increase in ACSL expression suggests that ketotic cows require enhanced oxidation of long-chain FA derived mainly from adipose tissue to meet energy requirements. A possible explanation for this finding could be that BHBA concentration in ketotic cows was $>1.2$ $\mathrm{mmol} / \mathrm{L}$, which indicates that ketotic cows in our study experienced a higher metabolic load than the cows in van Dorland et al. (2009).

The CPT system is composed of 3 enzymes, CPT I, carnitine-acylcarnitine translocase, and CPT II, and promotes the mitochondrial translocation of FA (Dann and Drackley, 2005). Carnitine palmitoyltransferase I is a membrane transporter of fatty acids (acyl-CoA)

Table 4. Protein levels of fatty acid metabolism-related enzymes in the liver of ketotic and nonketotic cows (means $\pm \mathrm{SE}$ )

\begin{tabular}{lcc}
\hline Item $^{1}$ & $\begin{array}{c}\text { Ketotic cows } \\
(\mathrm{n}=6)\end{array}$ & $\begin{array}{c}\text { Nonketotic cows } \\
(\mathrm{n}=6)\end{array}$ \\
\hline ACSL $(\mu \mathrm{g} / \mathrm{mg}$ of protein) & $4.45 \pm 0.59^{*}$ & $3.56 \pm 0.63$ \\
CPT I $(\mathrm{ng} / \mathrm{mg}$ of protein) & $86.34 \pm 24.49$ & $97.99 \pm 18.74$ \\
CPT II $(\mu \mathrm{g} / \mathrm{mg}$ of protein) & $8.91 \pm 2.78^{*}$ & $13.34 \pm 2.29$ \\
ACADL $(\mu \mathrm{g} / \mathrm{mg}$ of protein) & $11.28 \pm 1.47^{* *}$ & $17.50 \pm 1.66$ \\
HMGCS $(\mathrm{ng} / \mathrm{mg}$ of protein) & $80.10 \pm 16.27^{*}$ & $106.21 \pm 20.34$ \\
ACC $(\mathrm{ng} / \mathrm{mg}$ of protein) & $145.84 \pm 45.09^{*}$ & $200.29 \pm 36.29$ \\
Total protein in liver $(\mathrm{mg})$ & $3.22 \pm 0.23^{*}$ & $2.94 \pm 0.15$ \\
\hline${ }^{1}$ ACSL $=$ acyl-CoA synthetase long-chain; ACADL = acyl-CoA dehydrogenase long chain; CPT I = carnitine \\
palmitoyltransferase I; CPT II = carnitine palmitoyltransferase II; HMGCS = 3-hydroxy-3-methylglutaryl \\
CoA synthase; ACC = acyl-coenzyme A carboxylase.
\end{tabular}



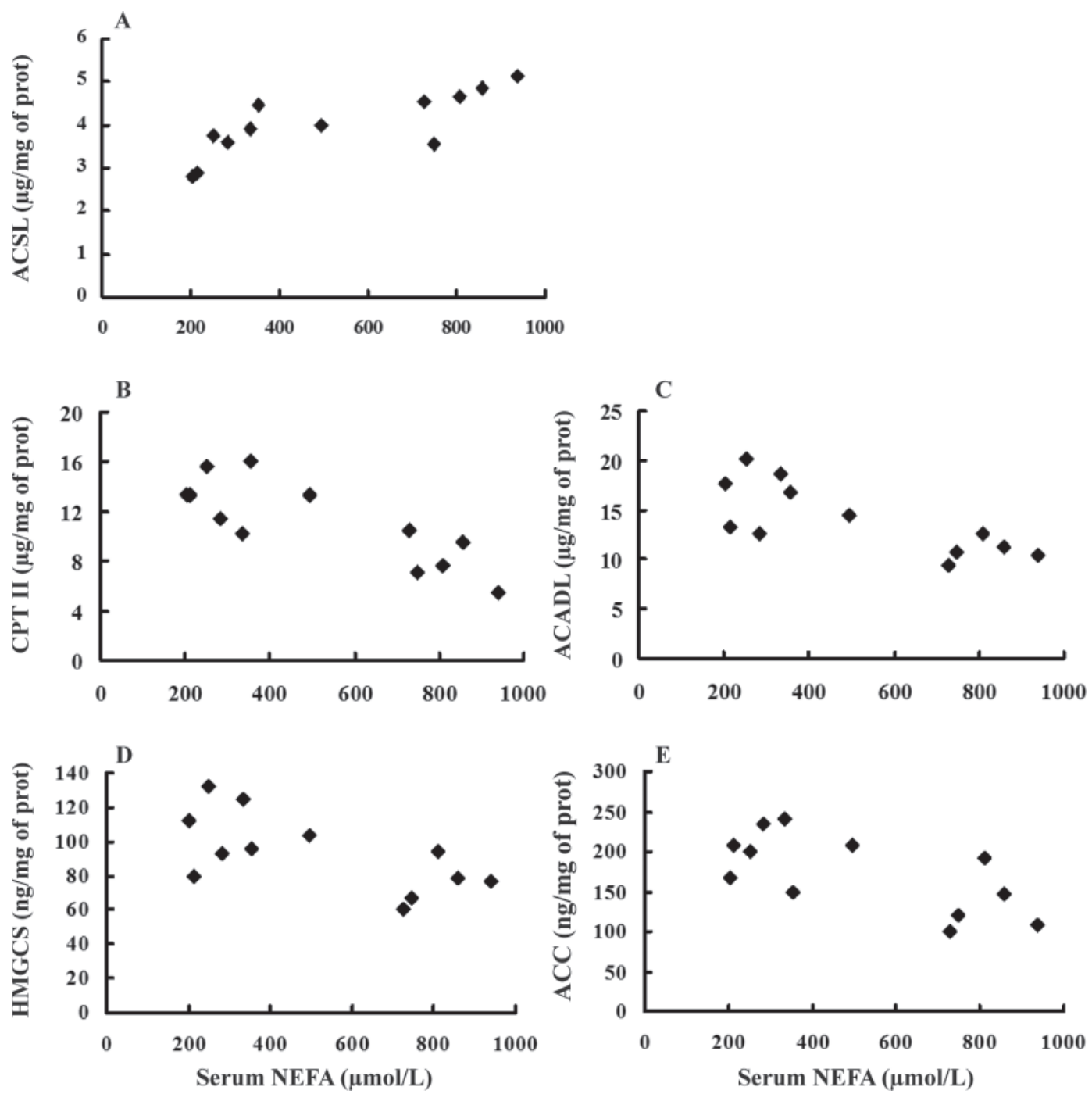

Figure 2. Correlations between serum NEFA concentration and acyl-CoA synthetase long-chain (ACSL), acyl-CoA dehydrogenase long chain (ACADL), carnitine palmitoyltransferase II (CPT II), 3-hydroxy-3-methylglutaryl CoA synthase (HMGCS), and acyl-coenzyme A carboxylase (ACC) protein levels in the liver of experimental cows. Serum NEFA concentration was positively correlated with $(\mathrm{A})$ ACSL $(\mathrm{r}=0.69, P=$ $0.013)$ and negatively correlated with (B) CPT II $(\mathrm{r}=-0.81, P=0.001),(\mathrm{C})$ ACADL $(\mathrm{r}=-0.75, P=0.005),(\mathrm{D})$ HMGCS $(\mathrm{r}=-0.63, P=$ $0.027)$, and $(\mathrm{E}) \mathrm{ACC}(\mathrm{r}=-0.67, P=0.018)$ content.

from the cytoplasm into the mitochondrial matrix and is a primary regulatory enzyme involved in mitochondrial $\beta$-oxidation. Long-chain FA oxidation is primarily controlled by changes in CPT I activity, malonyl-CoA concentration, and sensitivity of CPT I to inhibition by malonyl-CoA (Louet et al., 2001). In this study, CPT I mRNA levels and CPT II mRNA and protein levels were decreased. Lower expression of CPT I in ketotic cows is not attributed to an increase in malonyl-CoA, because the expression of ACC, which converts acetylCoA to malonyl-CoA, was lower in ketotic cows. Loor et al. (2005) observed increased CPT I mRNA levels with high serum NEFA concentrations after parturition. However, Xu et al. (2011) reported that CPT I tran- scription and translation were decreased significantly when NEFA concentrations exceeded $1.2 \mathrm{mmol} / \mathrm{L}$ in cultured bovine hepatocytes. The NEFA concentrations that downregulate CPT I expression in ketotic cows might be lower than that required by cultured bovine hepatocytes. Similar to levels of CPT I and CPT II, levels of mRNA and protein of ACADL, an enzyme catalyzing the first step of the $\beta$-oxidation of longchain FA in the mitochondria, were lower in the liver of ketotic cows. These findings suggest that the ability of $\beta$-oxidation of hepatocyte was decreased. A high level of fatty acyl-CoA was produced by the increased expression of ACSL and might be esterified to triacylglyceride, which results in liver lipidosis in ketotic cows. 

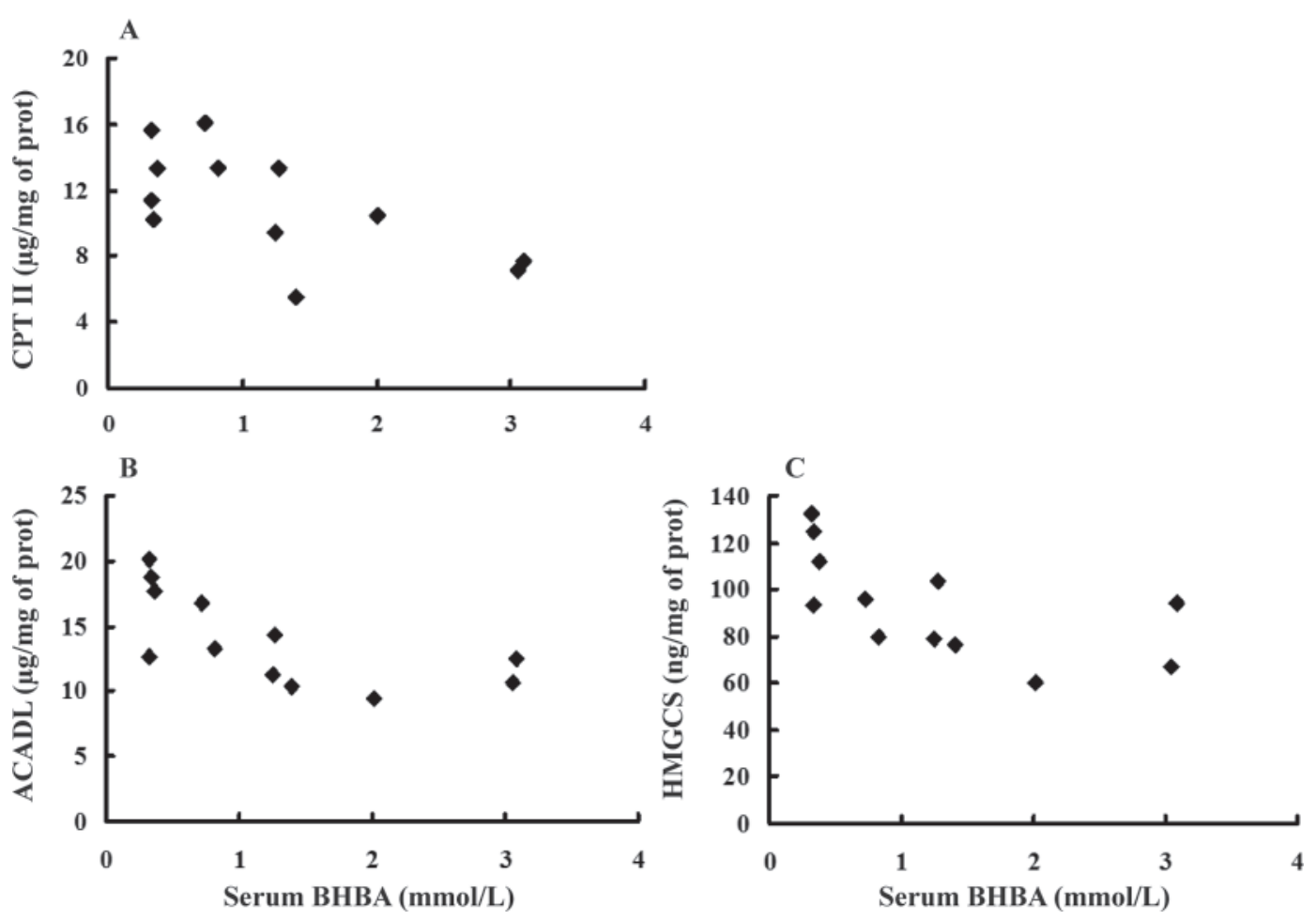

Figure 3. Correlations between serum BHBA concentration and protein levels of carnitine palmitoyltransferase II (CPT II), acyl-CoA dehydrogenase long chain (ACADL), and 3-hydroxy-3-methylglutaryl CoA synthase (HMGCS) in the liver of ketotic cows. Serum BHBA concentration was negatively correlated with (A) CPT II $(\mathrm{r}=-0.65, P=0.021)$, (B) ACADL $(\mathrm{r}=-0.66, P=0.020)$, and $(\mathrm{C})$ HMGCS $(\mathrm{r}=-0.61, P$ $=0.035)$ content.

However, the esterification process of fatty acid was not evaluated in the present study and additional research is needed to confirm our findings.

3 -Hydroxy-3-methylglutaryl-CoA synthase is the rate-limiting enzyme of the ketogenic pathway, regulating ketogenesis under several physiologic conditions such as fasting, prolonged exercise, and a high-fat diet. Starvation $(24 \mathrm{~h})$ increases not only HMGCS mRNA level (4-fold), but also HMGCS protein level (Hegardt, 1999). In the present study, HMGCS mRNA and protein levels were considerably lower in ketotic cows than in nonketotic cows, even though BHBA levels were elevated in ketotic cows. Similar to our finding, van Dorland et al. (2009) reported that the mRNA abundance of HMGCS2 in the high-BHBA cows (BHBA $>0.75 \mathrm{mmol} / \mathrm{L}$ ) in wk 4 postpartum was not higher than that of low-BHBA cows (BHBA $<0.75 \mathrm{mmol} / \mathrm{L}$ ), even though the BHBA concentration was significantly higher in wk 4 postpartum in high-BHBA than in lowBHBA cows. A possible explanation for this finding could be that the expression of HMGCS is regulated by feedback inhibition of high serum BHBA concentration (Ness and Chambers, 2000). However, reports about this are limited, especially in dairy cows.

As reported previously, FA regulate the expression of hepatic lipid metabolism-related genes (Mashek and
Grummer, 2003; Xu et al., 2011). We found that serum NEFA concentration was positively correlated with ACSL and negatively correlated with CPT II, ACADL, HMGCS, and ACC protein content, which indicates that high serum NEFA may regulate expression of those genes; however, a threshold concentration for this regulation is not known.

The metabolite BHBA, which was higher in ketotic cows than in nonketotic cows, may play a key role in FA metabolism. Stanley et al. (2003) reported that BHBA inhibits myocardial FA oxidation independent of changes in malonyl-CoA content. We found that serum BHBA concentration negatively correlated with CPT II, ACADL, and HMGCS protein levels, which suggests that BHBA may affect FA metabolism by regulating CPT II, ACADL, and HMGCS expression in the liver of ketotic cows; however, the underlying mechanism for this effect is unknown. These findings indicate that high concentrations of NEFA or BHBA may alter the metabolic process of FA in the liver of ketotic cows.

\section{CONCLUSIONS}

Fatty acid $\beta$-oxidation capability was altered in the liver of ketotic cows. Increased activation and decreased $\beta$-oxidation of FA suggests greater fatty acyl-CoA es- 
terification into triacylglyceride, which may lead to liver lipidosis. High serum NEFA and BHBA concentrations play key roles in metabolism of FA in ketotic cows.

\section{ACKNOWLEDGMENTS}

This work was supported by grants from the China National Science Foundation Committee (Grant Nos. 30871897, 31072178, and 30972224), and the Science Fund for Distinguished Young Scholars of Jilin University (Grant No. 201100009).

\section{REFERENCES}

Bobe, G., J. W. Young, and D. C. Beitz. 2004. Pathology, etiology, prevention, and treatment of fatty liver in dairy cows. J. Dairy Sci. 87:3105-3124.

Bradford, M. M. 1976. A rapid and sensitive method for the quantitation of microgram quantities of protein utilizing the principle of protein-dye binding. Anal. Biohem. 72:248-254.

Busato, A., D. Faissler, U. Kupfer, and J. W. Blum. 2002. Body condition scores in dairy cows: Associations with metabolic and endocrine changes in healthy dairy cows. J. Vet. Med. A Physiol. Pathol. Clin. Med. 49:455-460.

Dann, H. M., and J. K. Drackley. 2005. Carnitine palmitoyltransferase I in liver of periparturient dairy cows: Effects of prepartum intake, postpartum induction of ketosis, and periparturient disorders. J. Dairy Sci. 88:3851-3859.

Drackley, J. K., T. R. Overton, and G. N. Douglas. 2001. Adaptations of glucose and long-chain fatty acid metabolism in liver of dairy cows during the periparturient period. J. Dairy Sci. 84(E. Suppl.):E100-E112.

Duffield, T. 2000. Subclinical ketosis in lactating dairy cattle. Vet. Clin. North Am. Food Anim. Pract. 16:231-253.

Geishauser, T., K. Leslie, J. Tenhag, and A. Bashiri. 2000. Evaluation of eight cow-side ketone tests in milk for detection of subclinical ketosis in dairy cows. J. Dairy Sci. 83:296-299.

Goff, J. P., and R. L. Horst. 1997. Physiological changes at parturition and their relationship to metabolic disorders. J. Dairy Sci. 80:1260-1268

Grummer, R. R. 1995. Impact of changes in organic nutrient metabolism on feeding the transition dairy cow. J. Anim. Sci. 73:28202833

Hachenberg, S., C. Weinkauf, S. Hiss, and H. Sauerwein. 2007. Evaluation of classification modes potentially suitable to identify metabolic stress in healthy dairy cows during the peripartal period. J. Anim. Sci. 85:1923-1932.

Hegardt, F. G. 1999. Mitochondrial 3-hydroxy-3-methylglutaryl-CoA synthase: A control enzyme in ketogenesis. Biochem. J. 338:569582
Ingvartsen, K. L. 2006. Feeding-and management-related diseases in the transition cow: Physiological adaptations around calving and strategies to reduce feeding-related diseases. Anim. Feed Sci. Technol. 126:175-213.

Loor, J. J., H. M. Dann, R. E. Everts, R. Oliveira, C. A. Green, N. A. J. Guretzky, S. L. Rodriguez-Zas, H. A. Lewin, and J. K. Drackley. 2005. Temporal gene expression profiling of liver from periparturient dairy cows reveals complex adaptive mechanisms in hepatic function. Physiol. Genomics 23:217-226.

Louet, J. F., C. Le May, J. P. Pegorier, J. F. Decaux, and J. Girard. 2001. Regulation of liver carnitine palmitoyltransferase I gene expression by hormones and fatty acids. Biochem. Soc. Trans. $29: 310-316$

Mashek, D. G., and R. R. Grummer. 2003. Effects of long chain fatty acids on lipid and glucose metabolism in monolayer cultures of bovine hepatocytes. J. Dairy Sci. 86:2390-2396.

Melendez, P., J. P. Goff, C. A. Risco, L. F. Archbald, R. Littell, and G. A. Donovan. 2006. Incidence of subclinical ketosis in cows supplemented with a monensin controlled-release capsule in Holstein cattle, Florida, USA. Prev. Vet. Med. 73:33-42.

Murondoti, A., R. Jorritsma, A. C. Beynen, T. Wensing, and M. J. H. Geelen. 2004. Unrestricted feed intake during the dry period impairs the postpartum oxidation and synthesis of fatty acids in the liver of dairy cows. J. Dairy Sci. 87:672-679.

Ness, G. C., and C. M. Chambers. 2000. Feedback and hormonal regulation of hepatic 3-hydroxy-3-methylglutaryl coenzyme A reductase: The concept of cholesterol buffering capacity. Proc. Soc. Exp. Biol. Med. 224:8-19.

Stanley, W. C., S. R. Meadows, K. M. Kivilo, B. A. Roth, and G D. Lopaschuk. 2003. $\beta$-Hydroxybutyrate inhibits myocardial fatty acid oxidation in vivo independent of changes in malonyl-CoA content. Am. J. Physiol. Heart Circ. Physiol. 285:H1626-H1631.

van Dorland, H. A., S. Richter, I. Morel, M. G. Doherr, and N. Castro. 2009. Variation in hepatic regulation of metabolism during the dry period and in early lactation in dairy cows. J. Dairy Sci. 92:1924-1940.

Vernon, W. D., D. Giham, G. M. Hatch, L. B. Agellon, R. Lehner, and D. E. Vance. 2003. Regulation of triacylglycerol hydrolase expression by dietary fatty acids and peroxisomal proliferator-activated receptors. Biochim. Biophys. Acta 1635:20-28.

Xu, C., G. W. Liu, X. B. Li, C. Xia, H. Y. Zhang, and Z. Wang. 2010. Decreased complete oxidation capacity of fatty acid in the liver of ketotic cows. Asian-australas. J. Anim. Sci. 23:312-317.

$\mathrm{Xu}, \mathrm{C}$., and Z. Wang. 2008. Comparative proteomic analysis of livers from ketotic cows. Vet. Res. Commun. 32:263-273.

Xu, C., Z. Wang, R. H. Zhang, H. Y. Zhang, S. X. Fu, and C. Xia. 2011. Effect of NEFA and glucose levels on CPT-I mRNA expression and translation in cultured bovine hepatocytes. J. Vet. Med. Sci. 73:97-101. 